\title{
REVIEWERS OF THE „ENVIRONMENTAL PROTECTION AND NATURAL RESOURCES”
}

Vol. 28 No 1(71), 2(72), 3(73), 4(74), 2017

\author{
Dr Adamska Edyta \\ Dr hab. inż. Aleksander-Kwaterczak Urszula \\ Dr hab. Bórawski Piotr \\ Dr hab. inż. Brzeżański Marek, prof. nadzw. \\ Dr inż. Dymitryszyn Izabela \\ Prof. dr hab. Florek Wacław \\ Dr Głogowska Magdalena \\ Prof. dr hab. Gworek Barbara \\ Dr Iskra Krzysztof \\ Dr Kalinowski Radosław \\ Dr Kargulewicz Iwona \\ Dr hab. inż. Koda Eugeniusz, prof. nadzw. \\ Dr inż. Kondras Marek \\ Dr inż. Krawiec Krzysztof \\ Dr hab. Kryza Maciej \\ Dr Kubica Krystyna \\ Dr hab. Kucharski Leszek, prof nadzw. \\ Dr hab. inż. Leonowicz Zbigniew \\ Dr hab. Lorens Bogdan, prof. nadzw. \\ Prof. dr hab. Łabętowicz \\ Prof. dr hab. Madura Henryk \\ Dr hab. Majewski Grzegorz
}

\author{
Mgr inż. Miodoński Jan \\ Prof. dr hab. Okruszko Tomasz \\ Dr hab. inż. Piekarski Jacek, prof. nadzw. \\ Dr hab. inż. Pilecki Zenon, prof. nadzw. \\ Dr Pobereżny Jarosław \\ Dr hab. Porębska Grażyna, prof. nadzw. \\ Dr hab. inż. Rogula-Kozłowska Wioletta \\ Dr Sienkiewicz Jadwiga \\ Prof. dr hab. Skrzypczyńska Małgorzata \\ Dr hab. Somorowska Urszula, prof. nadzw. \\ Dr hab. inż. Sówka Izabela, prof. nadzw. \\ Prof. dr hab. Szulc Wiesław \\ Dr hab. Walosik Alicja, prof. nadzw. \\ Prof. dr hab. Wojdalski Janusz \\ Dr hab. Wójcik Roman \\ Dr. hab. Wójtowicz Bożena, prof. nadzw. \\ Dr inż. Wszelaczyńska Elżbieta \\ Prof. dr hab. Załęska-Radziwiłt Monika \\ Dr inż. Zydroń Tymoteusz \\ Dr inż. Żak Katarzyna \\ Dr hab. Żeber-Dzikowska llona, prof. nadzw. \\ Dr hab. Żukiewicz-Sobczak Wioletta, prof. nadzw.
}

The editors would like to publicly acknowledge the people who served as reviewers on the journal during 2017. Without their efforts, the quality of the journal could not be sustained. 